Jurnal PG-PAUD Trunojoyo : Jurnal Pendidikan dan Pembelajaran Anak Usia Dini, Volume 7, Nomor 2, Oktober 2020 hal 1-8, ISSN : 2528-3553 (online), ISSN: 2407-4454 (print)

\title{
EAMO STORY BOOK: BUKU EDUKASI AKHLAK DAN MORAL UNTUK ANAK USIA PRASEKOLAH
}

\author{
Primi Enggar Nammellen Ganesthy ${ }^{1}$ \\ Dina Afidah Oktaviyanah ${ }^{2}$ \\ 1,2Politeknik Elektronika Negeri Surabaya \\ email:primienggar@gmail.com,diinaafidah@gmail.com
}

Received (Juni), Accepted (September), Published (Oktober)

\begin{abstract}
EAMO Story Book: Buku Edukasi Akhlak dan Moral Untuk Anak Usia Prasekolah. Preschoolers are part of early childhood with an age range of 3-6 years. Presence of preschoolers is a crucial time for every individual. Preschool age is the age of golden age which has a big influence on their lives in the future. Early childhood and preschoolers need guidance from adults, both teachers and parents. A good community environment is also a determinant of children's growth and development in forming individuals with moral values and Islamic character. Ironically in this era of fast-paced technology, many parents are giving unfavorable parenting to their baby. Busyness of parents is one of the causes of addiction to children playing smartphones. Without close supervision from parents, in addition to being entertained, children can also be exposed to negative content from what they watch. By using the literature study method from secondary data and qualitative-descriptive analysis techniques, research on preschoolers who are addicted to devices gets a design solution in the form of learning tools based on Augmented Reality technology. The author packages the solution into a story book by utilizing the development of digital technology. This solution is expected to reduce children's addiction to playing smartphones, prevent them from negative content, and form individuals of religious character.
\end{abstract}

Keywords: Islamic Character Building, Gadget, Preschool

\begin{abstract}
Abstrak: EAMO Story Book: Buku Edukasi Akhlak dan Moral Untuk Anak Usia Prasekolah. Anak prasekolah merupakan bagian dari anak usia dini dengan rentang umur 3-6 tahun. Keberadaan anak prasekolah menjadi masa yang krusial bagi setiap individu. Usia prasekolah merupakan usia golden age yang berpengaruh besar untuk kehidupannya di masa mendatang. Anak usia dini dan anak prasekolah membutuhkan bimbingan dari orang dewasa, baik guru maupun orang tua. Lingkungan masyarakat yang baik juga menjadi penentu tumbuh kembang anak dalam membentuk pribadi berakhlak karimah dan berkarakter islami. Ironisnya di era teknologi yang serba cepat ini, banyak orang tua memberi pola asuh kurang baik kepada buah hati mereka. Kesibukan orang tua menjadi salah satu penyebab kecanduan anak bermain smartphone. Tanpa pengawasan yang ketat dari orang tua, disamping mendapat hiburan, anak juga bisa terpapar konten negatif dari apa yang mereka tonton. Dengan menggunakan metode studi literatur dari data sekunder dan teknik analisis kualitatif-deskriptif, penelitian terhadap anak prasekolah yang kecanduan gawai mendapat sebuah rancangan solusi berupa sarana pembelajaran berbasis teknologi Augmented Reality. Penulis mengemas solusi tersebut menjadi sebuah buku cerita dengan memanfaatkan perkembangan teknologi digital. Solusi ini diharapkan dapat mengurangi kecanduan anak bermain smartphone, menghindarkan mereka dari konten negatif, dan membentuk individu berkarakter religius.
\end{abstract}

Kata Kunci : Pendidikan Karakter Religius, Gawai, Prasekolah 
Jurnal PG-PAUD Trunojoyo : Jurnal Pendidikan dan Pembelajaran Anak Usia Dini, Volume 7, Nomor 2, Oktober 2020 hal 1-8, ISSN : 2528-3553 (online), ISSN: 2407-4454 (print)

\section{PENDAHULUAN}

Anak Prasekolah adalah anak yang berusia antara usia 3-6 tahun, serta biasanya sudah mulai mengikuti program presschool (Dewi, Oktiawati, Saputri, 2015). Pada masa ini anak sedang menjalani proses pertumbuhan dan perkembangan yang sangat pesat, sehingga membutuhkan stimulasi yang intensif dari orang di sekelilingnya agar mempunyai kepribadian yang berkualitas dalam masa mendatang (Muscari, 2005). Usia anak prasekolah merupakan bagian dari anak usia dini yang memiliki masa emas atau golden age bagi anak-anak. Pada usia ini, anak-anak mengalami pertumbuhan dan perkembangan fisik dan mental yang luar biasa. Usia anak prasekolah juga menjadi masa terpenting bagi anak dalam pembentukan kepribadian, watak, dan karakter yang utama.

Oleh karena itu, penting memberi penanaman nilai-nilai agama sejak dini agar tercipta manusia yang berakhlak mulia. Pendidikan agama Islam diberikan kepada anak sejak dini melalui pengenalan-pengenalan terlebih dahulu mengenai ciptaan Allah tentang alam dan seisinya. Kemudian dikenalkan ibadah terutama sholat, wudhu, membaca do'a sehari-hari. Juga diajarkan pembiasaan-pembiasaan yang bernuansa Islami agar terbentuk akhlak karimah. Dalam sebuah hadits yang diriwayatkan Al-Hakim, Rasulullah SAW bersabda:



"Tiada suatu pemberian yang lebih utama dari orang tua kepada anaknya selain pendidikan yang baik." (HR. Al Hakim: 7679).

Hadist di atas menjelaskan bahwa orang tua merupakan suri tauladan bagi anak-anaknya. Orang tua berkewajiban untuk mengenalkan ajaran agama islam buah hatinya. Apa yang diajarkan dan dilakukan oleh orang tua akan berdampak pada anak-anak mereka. Anak- anak juga akan meniru kebiasaan yang dilakukan oleh orang tuanya. Allah ta'ala berfirman,

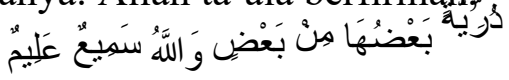

"Keturunan itu sebagiannya merupakan (turunan) dari yang lain." (Ali Imran: 34).

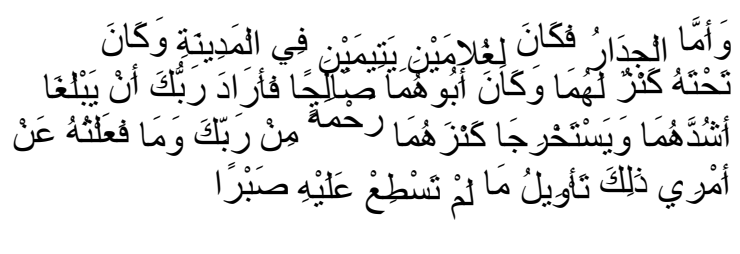

"Adapun dinding rumah itu adalah kepunyaan dua orang anak yatim di kota itu, dan di bawahnya ada harta benda simpanan bagi mereka berdua, sedang ayahnya adalah seorang yang saleh." (Al Kahfi: 82).

Ayat pertama menjelaskan orang tua yang baik, sumber yang baik, Insya Allah akan menghasilkan keturunan yang baik pula. Pada ayat kedua diberitakan bahwa dikarenakan keshalihan orang tua, Allah menjaga dan memelihara sang anak, serta tidak mengecewakan orang tua. Mayoritas penyebab kerusakan anak adalah akibat orang tua yang mengabaikan mereka, serta tidak mengajarkan berbagai kewajiban dan ajaran agama. Oleh karenanya, keshalihan orang tua itu akan berpengaruh pada sang anak, bahkan manfaat itu tidak terbatas pada sang anak semata, tapi juga berdampak positif kepada cucu-cucunya. Kesimpulan ayat-ayat di atas adalah orang tua memiliki kewajiban dalam memberikan pelajaran agama islam kepada anak-anaknya agar nantinya mereka menjadi insan yang berakhlaqul karimah dan selalu taat kepada Allah SWT.

Seiring berkembangnya teknologi modern, tidak sedikit dijumpai orang tua yang terlalu sibuk dengan pekerjaannya tidak dapat meluangkan waktu untuk memberikan pola asuh yang baik kepada buah hatinya. Dalam kacamata islam, sudah menjadi tanggung jawab orang tua untuk menjaga pergaulan anaknya. Realita yang terjadi banyak orang tua yang tidak 
Jurnal PG-PAUD Trunojoyo : Jurnal Pendidikan dan Pembelajaran Anak Usia Dini, Volume 7, Nomor 2, Oktober 2020 hal 1-8, ISSN : 2528-3553 (online), ISSN: 2407-4454 (print)

memahami betapa pentingnya perkembangan dan pertumbuhan anak pada masa golden age. Ironisnya, di era digital ini kebanyakan orang tua memanjakan anak mereka dengan memberikan dan membiarkan anak-anak bermain gadget. Tidak dapat dipungkiri, teknologi dapat membawa pengaruh negatif bagi anak-anak. Salah satu pengaruh negatif yang terlihat yaitu terkikisnya nilai agama dan moral pada diri anak. Sehingga, anak-anak sulit untuk menerima pelajaran yang disampaikan. Padahal, nilai-nilai agama sangat penting untuk diterapkan di dalam kehidupan manusia.

Syahra (2006) menyatakan bahwa semakin berkembangnya zaman tidak dapat dipungkiri bahwa perkembangan teknologi informasi dan komunikasi berlangsung semakin pesat dan penggunaannya telah menjangkau ke berbagai lapisan kehidupan masyarakat dari segala bidang, usia dan tingkat pendidikan. Penggunaan oleh orang dewasa, biasa digunakan untuk alat komunikasi, mencari informasi atau browsing, youtube, bermain game, ataupun lainnya. Sedangkan pemakaian pada anak usia dini biasanya terbatas dan penggunaannya hanya sebagai, media pembelajaran, bermain game, dan menonton animasi. Pemakaiannya pun dapat memiliki waktu yang beragam dan berbeda durasi serta intensitas pemakaiannya pada orang dewasa dan anak - anak.

Tak jarang ditemukan anak-anak usia dini dan anak prasekolah telah kecanduan bermain media sosial untuk melampiaskan rasa kesepiannya, baik itu dalam bentuk game online maupun video internet, yang justru dapat memperburuk keadaan mental, nilai moral, agama dan juga nilai sosialnya. Tidak ada jaminan media sosial terbebas dari konten-konten negatif, misalnya bisa saja ditengah video yang dilihat terdapat jeda iklan berisi konten dewasa. Ibarat kata, pengaruh teman sangatlah besar dalam membentuk karakter seorang anak.
Apabila anak menghabiskan waktunya untuk bermain game online atau melihat video youtube dan internet, otomatis teman sang anak adalah tontonan itu sendiri.

Sebagaimana sabda Rasulullah SAW, "Agama seseorang sesuai dengan agama teman dekatnya. Hendaklah kalian melihat siapakah yang menjadi teman dekatnya." (HR. Abu Daud dan Tirmidzi, dishahihkan oleh Syaikh Al Albani dalam Silsilah Ash -Shahihah, no. 927). Allah SWT menegaskan dalam firman- Nya yang berbunyi:

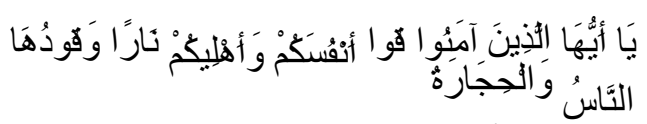

"Hai orang-orang yang beriman, peliharalah dirimu dan keluargamu dari api neraka yang bahan bakarnya adalah manusia dan batu." (At Tahrim: 6).

Ayat diatas mengandung arti anak-anak adalah bagian dari keluarga. Maka hendaklah orang tua mengajarkan tentang halal dan haram dan menjauhkannya dari kemaksiatan dan dosa, juga mengajarkan hukum-hukum lain selain tersebut.

Sesuai dengan anjuran Nabi SAW., mendidik anak prasekolah (3-6 tahun) dilakukan dengan mencurahkan kasih sayang penuh dan bersikap adil pada setiap anak. Karena pada saat itu fase seorang anak adalah dunia bermain yang dipenuhi dengan imajinasi. Maka pendidikan yang cocok adalah bermain. Orang tua tidak boleh memukul anaknya ketika berbuat salah, sekalipun atas dasar mendidik. Sehingga, anak-anak akan lebih dekat dan merasakan orang tua sebagai bagian dari dirinya saat besar, yang dapat dianggap sebagai teman dan rujukan yang terbaik.

Dengan demikian, untuk membangun dan meningkatkan pendidikan karakter anak usia dini yang mulai runtuh karena pengaruh gawai, maka dibutuhkan suatu inovasi yang sejalan dengan perkembangan teknologi saat ini. Kami menawarkan solusi berupa EAMO Story Book yaitu sebuah inovasi Buku Edukasi Akhlak dan Moral berbasis Augmented 
Jurnal PG-PAUD Trunojoyo : Jurnal Pendidikan dan Pembelajaran Anak Usia Dini, Volume 7, Nomor 2, Oktober 2020 hal 1-8, ISSN : 2528-3553 (online), ISSN: 2407-4454 (print)

Reality dengan memanfaatkan teknologi hologram 4 dimensi, yang menghasilkan kesan visual lebih nyata pada buku cerita. Selain itu, inovasi ini dilengkapi dengan perangkat khusus untuk mendeteksi barcode buku menggantikan smartphone.

Dengan adanya EAMO Story Book, kami berharap anak usia dini dengan rentang usia 3-6 tahun dapat leluasa belajar, bermain, dan berinteraksi dengan karakter dalam buku cerita sehingga mereka dapat terlepas dari kecanduan bermain gawai. Selain itu, adanya solusi ini dapat menjadi media pembelajaran untuk menanamkan karakter religius bagi anak prasekolah.

\section{METODE}

Metode pengumpulan data pada penelitian ini menggunakan konsep studi literatur. Studi literatur adalah sebuah cara untuk menyelesaikan persoalan dengan menelusuri sumber-sumber tulisan yang pernah dibuat sebelumnya. Studi literatur dilakukan dengan mencari referensi teori yang relevan dengan kasus atau permasalahan yang ditemukan. Sumber dari studi literatur yang kami gunakan meliputi Al-Qur'an, buku, dan publikasi-publikasi lain dari media internet atau daring.

Menurut Nazir (1988), metode deskriptif merupakan suatu metode dalam meneliti status sekelompok manusia, suatu objek, suatu set kondisi, suatu sistem pemikiran ataupun suatu kelas peristiwa pada masa sekarang. Tujuan dari penelitian deskriptif ini adalah untuk membuat deskripsi, gambaran, atau lukisan secara sistematis, faktual dan akurat mengenai fakta-fakta, sifat-sifat serta hubungan antarfenomena yang diselidiki. Sedangkan menurut Sugiyono (2005) menyatakan bahwa metode deskriptif adalah suatu metode yang digunakan untuk menggambarkan atau menganalisis suatu hasil penelitian tetapi tidak digunakan untuk membuat kesimpulan yang lebih luas. Menurut Whitney (1960), metode deskriptif adalah pencarian fakta dengan interpretasi yang tepat.

Metode penelitian dengan pendekatan kualitatif-deskriptif digunakan sebagai teknik analisis data yang dilakukan secara bertahap. Masalah yang dapat diteliti dan diselidiki oleh penelitian kualitatif deskriptif ini mengacu pada studi kuantitatif, studi komparatif, serta dapat menjadi sebuah studi korelasi antara satu unsur dengan unsur lainnya. Kegiatan penelitian ini meliputi pengumpulan data, analisis data, interprestasi data, merumuskan suatu kesimpulan dan diakhiri dengan memberikan solusi praktis sesuai dengan data dan perkembangan teknologi.

\section{HASIL DAN PEMBAHASAN}

Perkembangan teknologi dan komunikasi yang canggih memberikan dampak yang sangat besar terhadap dunia Pendidikan. Kemudahan dalam mengakses berbagai informasi dan hiburan telah banyak tersaji dalam bentuk online dan offline. Dampak kehadiran teknologi tidak hanya dirasakan oleh orang dewasa saja, tetapi pengaruhnya terhadap perkembangan dan Pendidikan anak usia dini juga sangat besar. Penggunaan smartphone sering kali disalahgunakan oleh sebagian pihak, seperti orang tua yang memanjakan anak mereka dengan memberi fasilitas gadget sebagai media hiburan bagi anak berusia dini. Berdasarkan penelitian yang telah dilakukan, penggunaan gadget untuk anak usia dini atau anak prasekolah sebagai berikut.

\section{Penelitian penggunaan gadget}

Sari dan Mitsalia (2016) melaporkan bahwa rata - rata anak menggunakan gadget untuk bermain game daripada menggunakan untuk hal lainnya. Hanya sedikit yang menggunakan untuk menonton kartun. Hasil dari penelitian Nurrachmawati (2014) menjelaskan bahwa PC tablet atau smartphone tidak hanya berisi aplikasi tentang pembelajaran 
Jurnal PG-PAUD Trunojoyo : Jurnal Pendidikan dan Pembelajaran Anak Usia Dini, Volume 7, Nomor 2, Oktober 2020 hal 1-8, ISSN : 2528-3553 (online), ISSN: 2407-4454 (print)

mengenal huruf atau gambar, tetapi terdapat aplikasi hiburan, seperti sosial media, video, gambar bahkan video game. Pada kenyataannya, anak-anak akan lebih sering menggunakan gadget-nya untuk bermain game daripada untuk belajar ataupun bemain di luar rumah dengan teman-teman seusianya.

Berdasarkan hasil penelitian yang dilakukan oleh The Asian Parent Insights pada November 2014, sebanyak 98 persen dari 2.714 orang tua di Asia Tenggara yang mengikuti penelitian ini mengizinkan anaknya untuk mengakses teknologi berupa komputer, smartphone, atau tablet. Penelitian ini dilakukan terhadap 2.714 orang tua di Asia Tenggara yang memiliki anak berusia $3-8$ tahun. Para orang tua peserta penelitian ini berasal dari Singapura, Malaysia, Thailand, Indonesia, dan Filipina. Dari hasil survey tersebut kebanyakan orangtua memperbolehkan anaknya bermain gadget untuk tujuan edukasi. Namun kenyataannya menurut hasil survey sebagian besar putra-putri mereka menggunakan gadget / tablet tersebut untuk tujuan hiburan seperti game.

Penelitian lain yang dilakukan oleh Delima, Arianti dan Pramudyawardani (2015), diperoleh hampir semua orang tua (94\%) menyatakan bahwa anak mereka biasa menggunakan perangkat teknologi untuk bermain game. Sebagian besar anak (63\%) menghabiskan waktu maksimum 30 menit untuk sekali bermain game. Sementara $15 \%$ responden menyatakan bahwa anak bermain game selama 30 sampai 60 menit dan sisanya dapat berinteraksi dengan sebuah game lebih dari satu jam.

Menurut Sari dan Mitsalia (2016), pemakaian gadget dikategorikan dengan intensitas tinggi jika menggunakan gadget dengan durasi lebih dari 120 menit /hari dan dalam sekali pemakaiannya berkisar $>$ 75 menit. Selain itu, dalam sehari bisa berkali - kali (lebih dari 3 kali pemakaian) pemakaian gadget dengan durasi $30-75$ menit akan menimbulkan kecanduan dalam pemakaian gadget. Selanjutnya, penggunaan gadget dengan intensitas sedang jika menggunakan gadget dengan durasi lebih dari 40-60 menit /hari dan intensitas penggunaanan dalam sekali penggunaan $2-3$ kali /hari setiap penggunaan. Penggunaan gadget yang baik adalah dengan kategori rendah yaitu dengan durasi penggunaan $<30$ menit /hari dan intensitas penggunaan maksimal 2 kali pemakaian.

\section{Analisis Data}

Berdasarkan data hasil penelitian di atas menunjukkan bahwa anak usia dini lebih senang menggunakan smartphone untuk bermain game daripada membuka aplikasi atau video pembelajaran. Karakteristik tampilan game yang interaktif dan menantang membuat anak-anak cenderung lebih menyukai menggunakan gadget untuk bermain. Kecenderungan anak dalam bermain game jika diukur dari data penelitian Sari dan Mitsalia (2016), maka data yang diperoleh dari penelitian Delima, Arianti dan Pramudyawardani pada tahun 2015 menunjukkan 63\% dari responden anak yang bermain gadget termasuk ke dalam kategori rendah, sekitar 22\% anak menggunakan gadget dengan kategori intensitas sedang, dan $15 \%$ sisanya masuk ke kategori pemakaian gadget dengan intensitas tinggi. Tidak dapat dipungkiri seiring berjalannya waktu, intensitas penggunaan gadget oleh anak usia dini atau anak prasekolah akan mengalami peningkatan menuju kategori tinggi. Oleh karena itu diperlukan pembatasan waktu dalam bermain game.

\section{Pengaruh gadget pada psikologi anak}

Banyaknya waktu yang dihabiskan oleh anak usia dini dalam menggunakan gadget dapat mempengaruhi kondisi psikologis anak. Menurut Handrianto (2013), penggunaan gadget pada anak-anak memiliki dampak positif dan juga negatif. Dampak tersebut antara lain adalah:

Dampak positif penggunaan gadget:

1) Berkembangnya imajinasi, (melihat gambar kemudian menggambarnya 
Jurnal PG-PAUD Trunojoyo : Jurnal Pendidikan dan Pembelajaran Anak Usia Dini, Volume 7, Nomor 2, Oktober 2020 hal 1-8, ISSN : 2528-3553 (online), ISSN: 2407-4454 (print)

sesuai imajinasinya yang melatih daya pikir tanpa dibatasi oleh kenyataan).

2) Melatih kecerdasan, (dalam hal ini anak dapat terbiasa dengan tulisan, angka, gambar yang membantu melatih proses belajar).

3) Meningkatkan rasa percaya diri. (saat anak memenangkan suatu permainan akan termotovasi untuk menyelesaikan permainan).

4) Mengembangkan kemampuan dalam membaca, matematika, dan pemecahan masalah. (dalam hal ini anak akan timbul sifat dasar rasa ingin tahu akan suatu hal yang membuat anak akan muncul kesadaran kebutuhan belajar dengan sendirinya tanpa perlu dipaksa).

Dampak negatif dari gadget adalah:

1) Penurunan konsentrasi saat belajar (pada saat belajar anak menjadi tidak fokus dan hanya teringat dengan gadget, misalnya anak teringat dengan permainan gadget seolah-olah dia seperti tokoh dalam game tersebut).

2) Malas menulis dan membaca, (hal ini diakibatkan dari penggunaan gadget misalnya pada saat anak membuka vidio di aplikasi Youtube anak cenderung melihat gambarnya saja tanpa harus menulis apa yang mereka cari).

3) Penurunan dalam kemampuan bersosialisasi, (misalnya anak kurang bermain dengan teman dilingkungan sekitarnya, tidak memperdulikan keadaan disekelilingnya.)

4) Kecanduan, (anak akan sulit dan akan ketergantungan dengan gadget karena sudah menajadi suatu hal yang menjadi kebutuhan untuknya).

5) Dapat menimbulkan gangguan kesehatan, (jelas dapat menimbulkan ganggunan kesehatan karena paparan radisasi yang ada pada gadget, dan juga dapat merusak kesehatan mata anak).

6) Perkembangan kognitif anak usia dini terhambat, (kognitif atau pemikiran proses psikologis yang berkaitan bagaimana individu mempelajari, memperhatikan, mengamati, membayangkan, memperkirakan, menilai dan memikirkan lingkungannya akan terhambat).

7) Menghambat kemampuan berbahasa, (anak yang terbiasa menggunakan gadget akan cendrung diam, sering menirukan bahasa yang didengar, menutup diri dan enggan berkomunikasi dengan teman atau lingkungannya).

8) Dapat mempengaruhi perilaku anak usia dini, (seperti contoh anak bermain game yang memiliki unsur kekerasan yang akan mempengaruhi pola perilaku dan karakter yang dapat menimbulkan tindak kekerasan terhadap teman).

Banyaknya dampak negatif penggunaan gadget oleh anak usia dini menunjukkan lebih besar pengaruhnya daripada dampak positif. Sangat disayangkan apabila anak terus dimanjakan dengan penggunaan gadget. Semakin lama anak bermain dengan gadget-nya, semakin kuat pula dampak negatif mempengaruhi perkembangan kognitif anak di usia golden age. Hal inilah yang akan merusak karakter anak. Di masa golden age, sudah sepantasnya pendidikan karakter religius diberikan kepada anak usia dini dan anak prasekolah. Pendidikan karakter religius nantinya dapat digunakan sebagai tameng dampak negatif.

\section{Pendidikan karakter religius}

Pendidikan karekter menjadi pilar utama yang harus dibentuk kepada setiap siswa. Pendidikan karakter terdiri dari lima nilai, yaitu: religius, nasionalisme, kemandirian, gotong royong, dan integritas. Keberadaan 
Jurnal PG-PAUD Trunojoyo : Jurnal Pendidikan dan Pembelajaran Anak Usia Dini, Volume 7, Nomor 2, Oktober 2020 hal 1-8, ISSN : 2528-3553 (online), ISSN: 2407-4454 (print)

nilai religius menjadi poin pertama yang harus diperhatikan para pendidik. Bahkan, nilai religius sudah seharusnya ditanamkan kepada anak sejak usia dini atau usia prasekolah. Karakter religius identik dengan tingkah laku agamis yang mengandung nilai-nilai positif. Sehingga, karakter religius menjadi modal awal untuk membentuk karakter yang lainnya.

Pendidikan karakter, menurut Kaimuddin (2014), merupakan usaha sadar yang terencana dan terarah melalui lingkungan pembelajaran untuk tumbuh kembangnya seluruh potensi manusia yang memiliki watak berkepribadian baik, bermoral-berakhlak, dan berefek positif konstruktif pada alam dan masyarakat. Lickona mendefinisikan pendidikan karakter sebagai upaya yang sungguh-sungguh untuk membantu seseorang memahami, peduli, dan bertindak dengan landasan inti nilai-nilai etis.

Sedangkan kata religius berasal dari kata religious yang berarti sifat religi yang melekat pada diri seseorang (Thantowi, 2012). Religius adalah sikap dan perilaku yang patuh dalam melaksanakan ajaran agama yang dianutnya, toleran terhadap pelaksanaan ibadah agama lain, dan hidup rukun dengan pemeluk agama lain (Suparlan, 2010). Pembentukan karakter religius terhadap anak tentu dapat dilakukan jika seluruh komponen stake holders pendidikan dapat berpartisipasi dan berperan serta, termasuk orang tua dari siswa itu sendiri.

Kementrian Lingkungan Hidup (Thantowi, 2012) menjelaskan lima aspek religius dalam Islam, yaitu:

1. Aspek Iman, menyangkut keyakinan dan hubungan manusia dengan Tuhan, malaikat, para Nabi dan sebagainya.

2. Aspek Islam, menyangkut frekuensi, intensitas pelaksanaan ibadah yang telah ditetapkan, misalnya solat, puasa, dan zakat.

3. Aspek ihsan, menyangkut pengalaman dan perasaan tentang kehadiran Tuhan, takut melanggar larangannya, dan lain-lain.

4. Aspek ilmu, menyangkut pengetahuan seseorang tentang ajaran-ajaran agama.

5. Aspek amal, menyangkut tingkah laku dalam kehidupan bermasyarakat, misalnya menolong orang lain, membela orang lemah, bekerja, dan lain sebagainya.

\section{SIMPULAN DAN SARAN}

Berdasarkan paparan di atas, semakin berkembangnya teknologi membuat karakter religius terhadap anak usia dini semakin melemah. Oleh karena itu, diperlukan sistem pembelajaran interaktif yang dapat menunjang pendidikan karakter religius anak usia dini di samping perkembangan teknologi yang semakin pesat.

Untuk mewujudkan hal tersebut, kami menyarankan solusi inovatif berupa sebuah buku edukasi akhlak dan moral berbasis teknologi Augmented Reality yang bernama EAMO Story Book. Teknologi Augmented Reality adalah teknologi yang menggabungkan benda maya dua dimensi dan ataupun tiga dimensi ke dalam sebuah lingkungan nyata tiga dimensi lalu memproyeksikan benda-benda tersebut dalam waktu nyata. Buku cerita ini menyajikan kisah-kisah nabi dan beberapa permainan disela-sela ceritanya yang mengandung cerminan pendidikan karakter religius. Dengan menerapkan teknologi AR tersebut, maka visualisasi cerita EAMO Story Book lebih terasa nyata dan dekat bagi anak usia dini, sehingga perhatian mereka akan lebih terpusat kepada jalan cerita.

Buku cerita berbasis Augmented Reality yang tersebar di pasaran umumnya membutuhkan smartphone untuk mengunduh sebuah aplikasi pemindai barcode yang dapat menampilkan cerita 3 dimensi. Menurut kami, akses tersebut kurang efektif dalam menanggulangi penggunaan gadget pada anak usia dini, 
Jurnal PG-PAUD Trunojoyo : Jurnal Pendidikan dan Pembelajaran Anak Usia Dini, Volume 7, Nomor 2, Oktober 2020 hal 1-8, ISSN : 2528-3553 (online), ISSN: 2407-4454 (print)

karena perhatian mereka kemungkinan besar masih tertuju pada aplikasi lain yang terdapat pada smartphone tersebut. Oleh karena itu, kami merancang sebuah alat akses yang berbeda untuk EAMO Story Book. Alat akses ini dirancang memiliki bentuk fisik seperti smartphone. Namun, hanya berisi aplikasi khusus pemindai barcode buku dan juga disertai alat pelacak lokasi yang menyala secara otomatis ketika proses pemindaian pada barcode dimulai. Hal ini memungkinkan orang tua memonitoring aktivitas anak dalam jarak jauh dengan ponsel mereka yang terhubung pada alat akses.

\section{DAFTAR PUSTAKA}

Delima, R., Arianti, N. K., \& Pramudyawardani, B. (2015). Identifikasi Kebutuhan Pengguna Untuk Aplikasi Permainan Edukasi Bagi Anak Usia 4 sampai 6 Tahun. Jurnal Teknik Informatika Dan Sistem Informasi, 1(1). https://doi.org/10.28932/jutisi.v1i1.56 $\underline{9}$

Dewi, R.C., Oktiawati, A., \& Saputri, L.D. (2015). Teori dan Konsep Tumbuh Kembang : Bayi, Toddler, Anak, dan Usia Remaja. Yogyakarta : Nuha Medika

Handrianto, P. (2013). Dampak Smartphone. Artikel. http://sainsjournalfst11.web.unair.ac.i d/artikel detail-75305-KESEHATAN Dampak\%20Smart\%20phone.html. Diakses 26 Januari 2020.

Kaimudin. (2014). Implementasi Pendidikan Karakter Dalam Kurikulum 2013. Jurnal Dinamika Ilmu volume 14 nomor 1 .
Muscari, Mary E. (2005). Keperawatan Pediatrik Edisi 3.Alih bahasa Alfrina. Jakarta : EGC.

Nazir, M. (1988). Metodologi Penelitian. Jakarta: Ghalia Indonesia.

Nurrachmawati. (2014). Pengaruh sistem operasi mobile android pada anak usia dini. Jurnal Pengaruh Sistem Operasi Mobile Android Pada Anak Usia Dini. Makasar: FT Universitas Hasanuddin.

Sari, P dan Mitsalia A. A. (2016). Pengaruh Penggunaan Gadget Terhadap Personal Sosial Anak Usia Pra Sekolah di TKIT Al Mukmin. Jurnal Profesi 13 (2) : 73 - 77.

Suparlan. (2010). Pendidikan Karakter:Sedemikian Pentingkah,dan Apakah yang Harus Kita Lakukan dalam suparlan.com. http:/www.suparlan.com/pages/posts/ pendidikan-karakter-sedemikianpentin gkah-dan-apa-yang-harus-kita-lakuka n-305.php Diakses 26 Januari 2020.

Sugiyono. (2005). Memahami Penelitian Kualitatif. Bandung: CV. Alfabeta

Syahra, R. (2006). Informatika Sosial Peluang dan Tantangan. Bandung: LIPI.

Thontowi, Ahmad. (2012). Hakekat Religiusitas. http://www.sumsel.kemenag.go.id , diakses 23 Februari 2020.

Whitney, F.L. (1960). The Elements of Resert.Asian Eds. Osaka: Overseas Book Co. 